\title{
O POETA E O PSICANALISTA: A INQUIETANTE ESTRANHEZA DO DUPLO
}

\author{
THE POET AND THE PSYCHOANALYST: THE WEIRDNESS OF THE DOUBLE \\ EL POETA Y EL PSICOANALISTA: EL CARÁCTER OMINOSO DEL DOBLE
}

\author{
Ingrid Vorsatz \\ Renata Dahwache Martins ${ }^{* *}$
}

\begin{abstract}
RESUMO
Este artigo pretende apresentar uma articulação entre psicanálise e literatura, partindo da premissa de que ambas têm como fundamento o campo da palavra e da linguagem, guardadas as devidas especificidades de cada um desses campos. Partiremos das próprias indicaçōes freudianas contidas em duas cartas de Freud endereçadas ao escritor e também médico vienense Arthur Schnitzler, seu contemporâneo, para problematizar aquilo que aproxima - bem como disjunta - o escritor-poeta (Dichter) do psicanalista. Ao nomear Schnitzler como o seu duplo (Doppelgänger), Freud assinala a estranha familiaridade entre os procedimentos psicanalítico e literário. A fim de situar a questão, faremos uma breve incursão sobre a noção germânica de Kultur, que caracteriza o solo comum entre Freud e Schnitzler. Contudo, Freud se distancia da perspectiva contida na ideia de cultivo de si (Bildung), integrante da Kultur, ao introduzir, no seio da civilização, um mal-estar irredutível.
\end{abstract}

Palavras-chave: Psicanálise. Literatura. Cultura. Duplo.

\begin{abstract}
This article intends to discuss the articulation between psychoanalysis and literature, starting from the premise that both have the field of word and language as a foundation, keeping the due particularities from each of these fields. Based on the Freudian indications, contained in two letters sent to the also Viennese doctor Arthur Schnitzler, his contemporary, to discuss what approaches (and, also disjoint) the poet-writer (Dichter) from the psychoanalyst. By naming Schnitzler as his double (Doppelgänger), Freud
\end{abstract}

\footnotetext{
Texto recebido em 29 de janeiro de 2017 e aprovado para publicação em 21 de fevereiro de 2018.

* Doutora em Teoria Psicanalítica pela Universidade Federal do Rio de Janeiro (UFRJ), professora adjunta no Instituto de Psicologia da Universidade do Estado do Rio de Janeiro (UERJ), professora colaboradora do Programa de Pós-graduação em Psicologia Social (IP-UERJ), coordenadora do projeto de pesquisa Psicanálise e Literatura: o campo da palavra e da linguagem como práxis (APQ3/FAPERJ). Endereço: Rua São Francisco Xavier, 524, Pavilhão João Lyra Filho, 10ª andar, sala 10.009 Bloco F - Maracanã, Rio de Janeiro-RJ, Brasil. Telefone: (21) 2334-0234. E-mail: ingrid.vorsatz@uerj.br.

* Graduada em Psicologia pela UERJ, residente do Curso de Especialização em Psicologia Clínica Institucional - Modalidade Residência Hospitalar, integrante do projeto de pesquisa Psicanálise e Literatura: o campo da palavra e da linguagem como práxis (APQ3/FAPERJ). Endereço: Rua São Francisco Xavier, 524, Pavilhão João Lyra Filho, $10^{\circ}$ andar, sala 10.034/2 Bloco E - Maracanã, Rio de Janeiro-RJ, Brasil. Telefone: (21) 97118-9978. E-mail: rdahwache@gmail.com.
} 
points out the strange familiarity between the psychoanalytical and literary procedures. In order to frame the question, a brief incursion will be made into the German notion of Kultur, as it characterizes the common ground of both Freud and Schnitzler. However, Freud distances himself from the perspective contained in the idea of self-cultivation (Bildung), integrating part of Kultur, as he introduces within the civilization, an irreducible discomfort.

Keywords: Psychoanalysis. Literature. Culture. Double.

\section{RESUMEN}

Este artículo intenta presentar una articulación entre psicoanálisis y literatura en la medida en que el fundamento de ambos es el campo de la palabra y del lenguaje, salvando las debidas especificidades de cada uno de ellos. Partiremos de las propias indicaciones freudianas contenidas en dos cartas al escritor y también médico vienés Arthur Schnitzler, su contemporáneo, para problematizar lo que aproxima y también aleja el escritor/poeta (Dichter) del psicoanalista. Al nombrar a Schnitzler como su doble (Doppelgänger) Freud señala una extraña familiaridad entre los procedimientos psicoanalíticos y literarios. A los fines de situar estas cuestiones haremos una breve incursión sobre la noción germana de Kultur, que es el terreno común entre Freud y Schnitzler. Sin embargo, Freud se aleja de la perspectiva contenida en la idea de Bildung, que pertenece a la Kultur, puesto que introduce en el núcleo de la civilización un malestar irreductible.

Palabras clave: Psicoanálisis. Literatura. Cultura. Doble.

"Necessitava eu de transverberar o embuço, a travisagem daquela máscara, a fito de devassar o núcleo dessa nebulosa - a minha vera forma" (Rosa, 2005, p. 116).

\section{INTRODUÇÃO}

$\mathrm{N}$

o âmago da Modernidade, identificada como o momento representado pelo autocentramento do sujeito como detentor de consciência de si, pautado na razão, surge o denominado Modernismo, que Birman (2000) define como sendo a "consciência crítica da Modernidade". A Wiener Moderne, também conhecida como a Viena fin-de-siècle, foi sede de um ambiente de fulcral importância cultural e intelectual, não apenas para o contexto austro-húngaro do fim do século XIX, mas em relação à Europa e ao mundo ocidental.

De acordo com Munk (2008), germinou nessa época um inquietante anseio de questionamento sobre o conhecimento e os discursos então instituídos. Tanto no âmbito das ciências, quanto nas artes, havia uma ânsia não apenas de 
novos ares, mas também de críticas ao autocentrado eu burguês. Os modernos vienenses se caracterizavam pelo questionamento das tradições, porém isso não se alinhava com um entusiasmo irrestrito pelos avanços e ideias de progresso da vida moderna, de inspiração iluminista, mas, sim, com as críticas em relação à modernização: nessa perspectiva, a Viena fin-de-siècle encontra o sentimento modernista.

Esse sentimento se apresenta no sentido de esvaziar a soberania desse todopoderoso Eu que detém a razão e a consciência sobre si e também da natureza. É nessa Viena, nesse caldo cultural (kulturell), que os médicos Sigmund Freud e Arthur Schnitzler (este último também escritor-poeta - Dichter) empreenderam sua démarche, ambos se valendo da palavra e da linguagem como instrumento de intervenção no real, cada um à sua maneira.

\section{KULTUR, BILDUNG E MAL-ESTAR (UNBEHAGEN) ${ }^{1}$}

Ao retomar o estudo de Elias a fim de discutir a tensão entre o pensamento freudiano e aquele da tradição do Romantismo alemão, no que diz respeito à cultura, Lo Bianco (1997) destaca a noção de Bildung, que assinala a maneira pela qual "os aspectos da cultura [Kultur] são desenvolvidos a partir do próprio cultivo desses aspectos num dado sujeito" (p. 4). Isso se daria a partir da ideia de um cultivo de si, uma espécie de autoformação ou autoeducação, que, por sua vez, desconsiderava o aspecto político da vida em sociedade.

Conforme indicado por Elias (1994), esse apoliticismo da classe média alemã fazia um contraponto com a perspectiva da burguesia francesa no século XVIII. O sociólogo indica que, entre a burguesia francesa e sua corte, as barreiras eram mais brandas, o que permitia participação daquela no meio político, podendo, assim, alcançar cargos de relevância. A tradição francesa tendia a uma harmonização entre política e produção cultural. Na Alemanha, esses limites eram mais acentuados. Havia praticamente nenhuma participação da classe média nas esferas políticas, salvo raras exceções (como a de Goethe em Weimar, por exemplo). Os costumes da corte eram repudiados e vistos como um cultivo fútil das aparências, sem qualquer valia à Kultur. O movimento conhecido como Romantismo alemão rechaçava os aspectos políticos, intimamente ligados à nobreza e à corte, chegando a ser considerado antigermânico qualquer pensamento que sobrepusesse a sociedade ao indivíduo; esse que era o eixo central de qualquer mudança e que, portanto, deveria estar em permanente processo de refino e aperfeiçoamento.

\footnotetext{
1 De acordo com Roudinesco (2016, p. 393), Freud teria considerado primeiramente o título Das Unglück in der Kultur (A infelicidade na cultura) para o artigo que viria a ser publicado em 1930, com o qual não teria ficado satisfeito, substituindo-o por Das Unbehagen in der Kultur (O mal-estar ou o descontentamento na cultura).
} 
Ao fim do século XVIII, Friedrich Schlegel fez um estudo sobre a história da arte e da literatura, trazendo, pela primeira vez, a reflexão de que o que é considerado belo é tributário de um determinado contexto histórico. A partir de uma análise desse estudo, Maas (2000) aponta que a historiografia da literatura alemã se constituiu com a intenção de atribuir uma identidade nacional à produção artística literária. De acordo com essa autora, o romance de formação (Bildungsroman) surge na mesma época, por meio desse esforço em alinhar um caráter nacional à literatura na Alemanha, delineando o romance de formação ou Bildungsroman como uma

Instituição social-literária, composta, por um lado, pelo conceito histórico da Bildung burguesa, fundamental para o funcionamento da sociedade absolutista tardia na Alemanha do final do século XVIII, e, por outro, pela grande instituição literária do mundo moderno, o romance (Maas, 2000, p. 14).

O Bildungsroman materializa os princípios da Bildung, tendo sua expressão paradigmática na obra Os anos de aprendizado de Wilhelm Meister (Goethe, 1795, citado por Maas, 2000), que aborda, essencialmente, o tema de "formar-se" (sich bilden), descrevendo um processo de permanente autoaperfeiçoamento (Maas, 2000).

O cultivo de si, presente na noção de Bildung, indica um longo e contínuo processo de aperfeiçoamento individual e subjetivo. Isso ocorreria por meio do domínio de si, mediante o qual o indivíduo deveria se autoeducar, formando, assim, uma interioridade regrada e coesa. Ademais, ele seria responsável pelo seu próprio autocultivo e pela construção de uma interioridade suficiente e plena, acreditando alcançar assim uma totalidade harmoniosa (Lo Bianco, 1997).

Freud não desconhecia os princípios morais contidos na noção de Bildung. Aliás, era um ávido leitor dos títulos capitais do Romantismo alemão e recebera, com muita honra, o Prêmio Goethe (Freud, 1930b/1996), ${ }^{2}$ que tem em vista homenagear "reconhecidas personalidades, cujas realizações criadoras são dignas de honrar a memória de Goethe" (Plänkers apud Bracco, 2011), ou seja, tratase de uma importante honraria cultural alemã. Lo Bianco (1997) assinala que era com a Kultur que Freud, fundamentalmente, dialogava. No entanto, nesse diálogo Freud não trata a Kultur da mesma forma que os românticos faziam, conforme discutiremos a seguir.

No ensaio $O$ mal-estar na civilização, Freud (1930a/2011) apresenta uma definição de cultura como servindo a dois fins: de um lado, como proteção contra a natureza e, de outro lado, a título de regulamentadora dos vínculos entre os

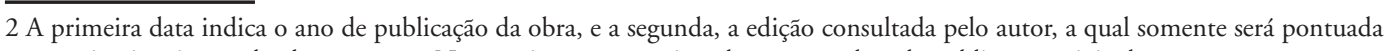
na primeira citação da obra no texto. Nas seguintes, será registrada apenas a data de publicação original. 
homens. Define Kultur como a "Inteira soma das realizações e instituições que afastam a nossa vida daquela de nossos antepassados animais" (Freud, 1930a, p. 34), e, ainda, como o cultivo e estima "das atividades psíquicas mais elevadas, das realizaçóes intelectuais, científicas e artísticas" (Freud, 1930a, p. 39). Vemos que essas proposiçóes se encontram afinadas à ideia de Kultur compartilhada pela tradição romântica. Porém, ao introduzir na relação do homem com a civilização um permanente conflito, Freud se distancia desse ideal de cultura, inoculando em seu cerne um mal-estar ineliminável.

Abordaremos o problema com base em um recorte sobre as considerações de Freud acerca das relaçôes entre sujeito e cultura, destacando duas inflexões distintas. Na primeira, formulada em 1908, é possível identificar certa perspectiva de concerto $^{3}$ na relação entre sujeito e cultura; já de acordo com a segunda, de 1930 (portanto, marcada pelo segundo dualismo pulsional, vale dizer, por levar em consideração a pulsão de morte como uma força silenciosa e disjuntiva, permanentemente em atuação recíproca às forças da vida, eróticas), um acordo não é mais possível. Vejamos o argumento freudiano, a seguir.

Em seu artigo A moral sexual civilizada e nervosismo moderno, Freud (1908a/1996) empreendeu um estudo da relação entre a sociedade moderna, em sua constituição então a pleno vapor, e o surgimento, cada vez mais comum à época, das neuroses. Para tanto, apresentou a argumentação de alguns estudiosos que se propuseram a realizar uma análise semelhante, verificando que era quase unânime a ideia de que a agitada vida moderna era a maior causa desse "nervosismo". O que Freud assinala, sem discordar inteiramente dos autores por ele mencionados, é que havia algo além dessa explicação, aparentemente superficial. Esse algo repousaria sobre aquilo que ele então recolhia em sua escuta na clínica. Seus pacientes queixavam-se de seus impasses em relação à sexualidade e, conforme destacado neste ensaio, sobre a repressão que a sociedade impunha sobre a sua expressão (Freud, 1908a). Termina por concluir que a vida em sociedade exige de cada sujeito a renúncia de uma parcela de satisfação pulsional (Freud, 1908a). Este, para conviver com os demais, desviaria uma parte da pulsão sexual para outras atividades, tais como o trabalho ou ainda as produçóes culturais, tidos como benéficos para a vida social. No entanto, ressalva que não seria possível deslocar toda a magnitude da energia pulsional para outras atividades e, em consequência disso, alguns fenômenos substitutivos surgiriam (os sintomas neuróticos). Sustenta que o surgimento do "nervosismo moderno" estaria alinhado ao aumento da repressão social à sexualidade (Freud, 1908a).

É importante sublinhar que, neste momento, o conceito de pulsão de morte e o segundo dualismo pulsional não haviam sido elaborados por 
Freud. Entretanto, já em 1908, encontramos a afirmação de que a relação entre o sujeito e a civilização é fonte de conflito. Apesar disso, Freud ainda considera uma harmonia possível, em que a repressão excessiva poderia ser abrandada e o homem poderia encontrar certo equilíbrio entre um quantum de satisfação sexual possível e, de outra parte, estaria franqueada a via da sublimação. Se, naquele momento, uma pretensa harmonia ainda se encontrava no horizonte, cerca de 20 anos mais tarde, no ensaio Mal-estar na civilização, Freud (1930a) afirmará a existência de um mal-estar irredutível ao laço social.

Freud (1930a) problematiza a felicidade como uma meta a ser alcançada pelos homens. Esta teria dois aspectos: o primeiro diria respeito a evitar sensações desprazerosas ou dolorosas, e o segundo teria por objetivo a vivência de intensos prazeres. No entanto, esse imperativo à felicidade, afinado ao programa do princípio de prazer, está em constante dissenso no que diz respeito à inserção do homem na vida social. Conforme já havia anunciado em seus Estudos sobre a histeria (Freud (1895/1996), o método clínico que estava em vias de formular implicaria um grande ganho se viesse a transformar a miséria neurótica em infelicidade comum. Em 1930, já não é somente com esta infelicidade banal que o homem está fadado a viver, mas também com um mal-estar irremediável, tributário da exigência de renúncia pulsional em jogo na Kultur.

Assim, a felicidade passa a ser considerada por Freud um "fenômeno episódico" (Freud, 1930a, p. 20), contrariando o anseio humano por um estado duradouro e perene. O programa imposto pelo princípio de prazer de busca pela felicidade seria irrealizável, já que não é possível satisfazer os imperativos pulsionais sem que isso culmine em uma radical divergência com os valores prezados pela cultura. É nesse sentido que a cultura é mediadora das relações interpessoais. Freud (1930a) aponta que, sem a mediação imposta pelas regras sociais, o que prevaleceria seria a lei do mais forte (isto é, a lei da selva). Em uma carta endereçada a Einstein, a propósito das guerras, Freud (1932/1996), retomará essa questão ao demarcar que a mediação cultural permite o caminho de desenvolvimento de um sistema de direito, ou ainda de justiça, cuja finalidade seria a de contenção à violência e à barbárie - ao preço de uma renúncia, ela mesma implicando em um mal-estar na cultura de caráter ineliminável.

Freud (1930a) indica as três fontes de mal-estar: a onipotência da natureza; a fragilidade do corpo, fadado à doença e à morte; e a relação entre os homens. As duas primeiras apontam para uma rendição ao inevitável: apesar dos avanços tecnológicos, a natureza nunca é plenamente domada e o corpo humano está submetido à dor e à morte, "fadado ao declínio e à dissolução" (Freud, 1930a, p. 20). Já em relação à terceira fonte de mal-estar, ele adverte que apesar da impressão de que a vida civilizada traria uma garantia de proteção e bem-estar, 
ela não o faz: "Esta [a terceira fonte de sofrimento] não queremos admitir, não podendo compreender por que as instituições por nós mesmas criadas não trariam bem-estar para todos nós" (Freud, 1930a, p. 30).

De acordo com sua argumentação, a ideia propagada pela cultura é a de que a maioria (isto é, a sociedade) é maior o que o indivíduo: "A liberdade individual não é um bem cultural" (Freud, 1930a, p. 41). Para poder viver com os demais, o homem deve abrir mão de certas liberdades, restringidas pelo social e endossadas pela instituição da justiça. Assim, a cultura (Kultur) é construída sobre uma renúncia pulsional. Essa "frustração cultural" (Freud, 1930a, p. 43), isto é, imposta pela cultura que rege o laço social, tem por efeito um mal-estar ineliminável. Consequentemente, o conflito que se instaura é permanente e insolúvel - vale dizer, estrutural.

De outra parte, Freud (1930a) evidencia que o sofrimento neurótico ocorre em detrimento da satisfação pulsional, às frustrações inerentes à sexualidade. Os sintomas neuróticos seriam gratificações substitutivas à renúncia pulsional, emergindo como um derivado distorcido da realização de desejo inconsciente (Freud, 1919a/1996). Isto é, para que haja vida em sociedade, em outras palavras, Kultur, uma renúncia se impõe a cada sujeito; mas essa própria renúncia produz satisfaçõos substitutivas (a neurose), que, por sua vez, tem um caráter associal (Freud, 1913b/2013, p. 72). Assim, a questão assinala um impasse, visto que o mal-estar se impõe, incontornavelmente.

Vemos, portanto, que a partir da perspectiva freudiana, a hipótese de uma sociedade harmoniosa, em que todos estariam libidinalmente satisfeitos, formando laços por meio do trabalho e sustentada em interesses em comum é veemente descartada. Freud afirma que há um fator de perturbação ainda não revelado. Acompanhando a sua argumentação, haveria uma pista a ser seguida com base no mandamento cristão, a seu ver inexequível, considerado como uma das exigências ideais da civilização ocidental: "Ama teu próximo como a ti mesmo". Freud assinala a impossibilidade desse amor incondicional. Esse próximo, conclui, mereceria muitas vezes mais a hostilidade do que o amor, isso porque não hesita em causar dano, caso isso lhe seja vantajoso (Freud, 1930a).

De modo geral, o outro, o semelhante, é considerado como um parceiro no campo social, numa colaboração que torna a vida em comum mais estratégica do que a individual, conforme já indicado. No entanto o que Freud justamente parece apontar é que o ser humano não é apenas dotado da capacidade de colaboração. Na mesma medida, o homem, entre seus "dotes pulsionais", dispõe de uma grande parcela de agressividade. Assim, o próximo não é apenas um colaborador e possível objeto sexual (sem conotação pejorativa): ele é também 
objeto de satisfação em relação às pulsões agressivas (Freud, 1930a). Vejamos em que termos Freud situa a questão:

Para ele [o homem], o próximo não constitui apenas um possível colaborador e objeto sexual, mas também uma tentação para satisfazer a tendência à agressão, para explorar seu trabalho sem recompensá-lo, para dele se utilizar sexualmente contra sua vontade, para usurpar seu patrimônio, para humilhá-lo, para infligir-lhe dor, para torturá-lo e matá-lo. Homo homini lupus; quem, depois de tudo o que aprendeu com a vida e a história, tem coragem de discutir esta frase? (Freud, 1930a, p. 57)

Freud assinala que essa tendência à agressão é um fator perturbador da vida em sociedade, ameaçando permanentemente sua existência. A cultura, dessa forma, impõe sacrifícios não apenas em relação à sexualidade, mas também à agressividade; uma disposição pulsional "original e autônoma do ser humano" (Freud, 1930a, p. 67), que é encontrada não apenas em relação ao próximo, mas também no que diz respeito a si mesmo. Dessa maneira, o homem cultural que Freud propõe (distanciando-se dos princípios morais da Bildung) não é unívoco, sequer é passível de vir a constituir uma totalidade, menos ainda harmoniosa. Esse homem do qual Freud traça os contornos é não idêntico a si mesmo, carrega consigo duas forças pulsionais opostas (Eros e Tanatos) que estão em constante duelo.

Quando anunciou, em Além do princípio do prazer (Freud, 1920/1996), que havia algo além das pulsões de autoconservação e que esse algo, ao contrário da busca por satisfação, buscava o retorno ao inorgânico (isto é, à morte), Freud já apontava uma tendência à autodestruição sempre presente, em contraponto à pulsão sexual. No entanto, esse empuxo à destruição é temperado por Eros; por outro lado, o homem desloca parte dessa pulsão para o exterior. Importante ressaltar que Freud (1930a) faz a ressalva de que as pulsóes nunca surgem isoladas. Eros e Tanatos se fundem e se tornam indistinguíveis. Assinala ainda que não há uma divisão qualitativa entre as forças pulsionais: ambas são indispensáveis em relação aos os fenômenos da vida, quase nunca agindo isoladamente (Freud, 1932). O ponto de articulação entre a teoria das pulsões e a cultura dar-se-ia, justamente, naquilo que o mal-estar justamente vem balizar: "Que ao mesmo tempo é condição para o exercício da pulsão e barra o seu destino de moção inapreensível" (Lo Bianco, 1997). Portanto, o mal-estar é o preço a pagar pela renúncia pulsional exigida pela Kultur. 


\section{A ORIGEM DA CRIAÇÃO POÉTICA (POIESIS)}

Em um breve ensaio sobre a gênese da criação poética, Freud (1908b/2015) a identifica junto às brincadeiras infantis, amparando-se na sabedoria da língua corrente alemã. Nesta, o radical spiel está presente tanto no verbo spielen, polissêmico como seu equivalente inglês play (brincar/jogar/atuar/representar), quanto nos substantivos Schauspielhaus (teatro), Schauspieler(in) (ator/atriz). Além de Trauerspiel (tragédia) e Lustspiel (comédia), gêneros da dramaturgia. Vale lembrar que, no teatro grego, as peças eram escritas sob a forma de versos, assim como grande parte da obra shakespeariana. Freud destaca que a própria linguagem sustenta essa afinidade entre brincadeira infantil e criação poética (Freud, 1908b, p. 54).

Em sua análise sobre a origem do fazer literário, Freud aproxima-o à brincadeira em que a criança, mobilizando um grande quantum de afeto, cria o mundo por meio de sua brincadeira/jogo (Spiel), tomando emprestado elementos da realidade (Wirklichkeit) e transformando-os em material passível de representação. Vale dizer, institui uma nova ordem (o jogo/brinquedo) e, nessa medida, comportase como o poeta (Dichter), criando o seu próprio mundo, dotado de efetividade (Freud, 1908b, p. 54). Desse modo, o fazer poético aproxima-se do brincar. O poeta/criador (Dichter) é aquele que joga, que maneja a palavra como seu instrumento de trabalho e cria o mundo no qual habita por meio da linguagem.

Freud (1908b) destaca outra relação em relação ao binômio brincadeira (Spiel)-realidade (Wirklichkeit), assinalando a presença de uma disposição anímica na qual essa oposição é suprimida: o humor, que implica um ganho de prazer. Uma vez que, na vida psíquica, nada é mais difícil do que renunciar ao prazer um dia experimentado, finda a infância - e, com ela, os jogos e as brincadeiras -, a fantasia passa a caracterizar o sucedâneo psíquico da brincadeira infantil, preservando assim o prazer um dia conhecido.

Não obstante, à diferença da brincadeira infantil, o adulto reluta em revelar as suas fantasias, afirma Freud, uma vez que estas são oriundas de desejos que deveriam permanecer ocultos, inclusive do próprio sujeito. Têm-se acesso a essas formações psíquicas pela clínica das neuroses, mais precisamente da histeria. Freud assinala que a fantasia encena uma realização de desejo, e sua força motriz (Triebekräfte) diz respeito à realização de um desejo insatisfeito (Freud, 1908b, p. 57). Não se trata de um desejo qualquer, ordinário, mas do desejo inconsciente, bem entendido.

Freud então retoma a problemática sobre a gênese da criação poética, estabelecendo uma espécie de comparação ou ainda de analogia entre, de um 
lado, o sonho diurno ou devaneio e a criação poética - ambos tecidos na e pela linguagem-, e, de outro, o sonhador diurno e o poeta (Dichter), destacando que a criação literária é, assim como sonho diurno, um prolongamento das brincadeiras infantis (Freud, 1908b, pp. 62-63). Se, conforme havia afirmado, o sucedâneo do brincar é o fantasiar, e este atualiza, encenando, uma realização de desejo inconsciente, então a criação poética, em certa medida, pereniza o jogo (Spiel) infantil, sustentando a realização de desejo de acordo com a atemporalidade que rege o inconsciente (das Unbewusste).

Contudo Freud já havia indicado que a revelação da fantasia, sucedâneo da brincadeira, despertaria um afeto desprazeroso. Como, então, considerar o efeito de fruição despertado pela criação artística/poética? Freud considera que nisso reside precisamente a Ars poetica:

O poeta suaviza o caráter do sonho diurno egoísta [individual] por meio de alterações e ocultamentos, e nos espicaça por meio de um ganho de prazer puramente formal, ou seja, estético, o qual ele nos oferece na exposição de suas fantasias. Pode-se chamar este ganho de prazer [...] de um prêmio por sedução [Verlockungspräie] ou de um prazer preliminar [Vorlust] (Freud, 1908b, p. 64, grifo do autor).

Assim, considera a fruição poética mediante um ponto de vista econômico, de acordo com o qual esta diria respeito a um ganho de prazer experimentado devido à liberação da tensão psíquica - de forma análoga à catarse. Essa possibilidade deve-se ao fato de que o poeta, tomando para si a tarefa de suavizar a realização de desejo inconsciente por meio das "alterações e ocultamentos" que caracterizam a própria criação poética, permite-nos "gozarmos com nossas fantasias sem censura e vergonha" (Freud, 1908b, p. 64). Vale dizer, sem que tenhamos de nos haver com a realização de desejo que nela se realiza - o poeta, em certa medida, tomaria para si essa responsabilidade.

Alguns anos mais tarde, Freud adota uma perspectiva diversa quanto à gênese da criação poética, afirmando que

As forças pulsionais da arte são os mesmos conflitos que impulsionam outros indivíduos à neurose e que incentivaram a sociedade a construir suas instituiçôes. De onde o artista retira sua capacidade criadora não constitui questão para a psicologia (Freud, 1913a/1997, tradução livre, grifo nosso).

A partir de então, a problemática referente a potência criadora (poiesis) deixa de ser objeto de análise e, ou, de especulação por parte de Freud. Como toda criação que se preza, esta é ex nihilo, ainda que as forças pulsionais em jogo sejam as mesmas que produzem tanto a doença neurótica como a própria civilização (Kultur) e seus avatares. 


\section{O ESCRITOR-POETA (DICHTER) COMO DUPLO DO PSICANALISTA}

O médico e psicanalista galês Ernest Jones, integrante da chamada primeira geração de psicanalistas, chama a atenção para o fato de que, apesar das inúmeras e diferentes abordagens freudianas acerca das questóes concernentes à arte e ao artista, Freud tinha em mente não o que hoje chamaríamos de artista plástico (pintor, escultor, gravador, entre outros), mas o escritor-poeta, Dichter, aquele que cria mediante a linguagem e tem na palavra o seu instrumento. $\mathrm{O}$ autor considera que Freud não cultivava especialmente nenhuma forma de apreciação estética, exceto em relação à literatura (Jones, 1989) - o que a impressionante coleção de antiguidades que Freud amealhou ao longo da vida desmente. Consta ainda que ele teria mencionado a Martha Bernays, então sua noiva, um breve arroubo literário, sem maiores consequências, em uma carta curiosamente datada de $1^{\circ}$ de abril de 1884 (Jones, 1989, pp. 403, 408-409).

Em sua primeira incursão na análise de uma obra literária ${ }^{4}$ como um todo, a propósito da novela Gradiva, de Wilhelm Jensen, e, mais especificamente, quanto ao trabalho do Dichter, Freud afirma que "A descrição da mente [Seele] humana é, na realidade, seu campo mais legítimo; desde tempos imemoriais ele [o Dichter] tem sido um precursor da ciência e, portanto, também da psicologia científica" (Freud, 1907/1977, p. 50). Vemos que, desde cedo, em sua obra, Freud assinala o improvável parentesco entre o trabalho realizado pelo homem de letras e aquele do psicanalista, afirmando, surpreendentemente, que a ficção do primeiro precede os achados clínicos do segundo.

É consensual entre os biógrafos de Freud o fato de que ele não travou conhecimento com o médico e escritor vienense Arthur Schnitzler, apesar de ser um admirador de suas criações literárias. ${ }^{5}$ Filho de um renomado médico vienense, Johann Schnitzler, apenas após a morte deste passou a se dedicar exclusivamente à literatura, ofício que antes partilhava com o de médico. Um de seus irmãos, Julius (também médico), costumava frequentar a casa de Freud, de quem era próximo, como integrante de um pequeno grupo que se reunia regularmente para jogar cartas. Apesar de sua amizade com Julius Schnitzler, Freud nunca chegou a conhecer pessoalmente o irmão mais velho.

Consta que Freud, ao longo da vida, teria redigido cerca de 20 mil cartas, a um sem-número de destinatários. Destas, apenas a metade se conservou (Roudinesco,

\footnotetext{
4 Segundo Jones (1989), a primeira a ter sido publicada. Na correspondência de Freud a Fliess, teria havido a menção a um estudo sobre a estória Die Richterin (A juiza), de Conrad Ferdinand Meyer, ofertada por Fliess ao seu então amigo Freud. A primeira análise de um personagem da literatura foi levada a cabo por Freud, em A interpretação de sonhos (Freud, 1900/1996), a propósito do herói shakespeariano Hamlet (Jones, 1989, pp. 413-414).

5 Jones (1989, p. 15) registra um único encontro entre Freud e Schnitzler, no mês de junho de 1922. Portanto, após a carta de Freud de 14 de maio daquele ano, na qual afirmara que não conhecia pessoalmente o escritor que encarnava o seu duplo (Doppelgänger), conforme a seguir.
} 
2016, p. 9). Apesar de ser um missivista de primeira linha, a relação epistolar entre Freud e Schnitzler teve como fruto apenas dez cartas, escritas entre 1906 e 1931, de acordo com Trachtenberg (2002), sendo que a primeira carta de Freud ao escritor foi uma resposta aos cumprimentos enviados por Schnitzler pelo seu cinquentenário, no ano de 1906. Diz a carta:

Há muitos anos estou ciente da ampla harmonia que existe entre as suas opiniōes e as minhas sobre muitos problemas psicológicos e eróticos; e recentemente [. . .] encontrei até coragem de acentuar expressamente esta harmonia. Sempre me perguntei espantado como o senhor havia chegado a este ou aquele detalhe do conhecimento secreto que eu havia adquirido mediante acurada investigação do tema, e finalmente cheguei ao ponto de invejar o autor que até então admirava. Agora o senhor pode imaginar como fiquei satisfeito e eufórico ao ler que o senhor também tem se inspirado nos meus escritos. Quase lastimo pensar que tive que alcançar cinquenta anos para ouvir algo tão lisonjeiro (Freud, carta datada de 8 de maio de 1906, apud Trachtenberg, 2002, grifo nosso).

É notável que, em seu primeiro contato com o escritor, Freud assinale a semelhança (harmonia, em seus termos) entre os achados literários de Schnitzler e seus próprios, clínicos e teóricos - vale dizer, científicos. Muitos anos mais tarde, em 14 de maio de 1922, por ocasião do sexagésimo aniversário de Schnitzler, Freud enviou-lhe outra carta, dessa vez contendo a íntima revelação de que havia encontrado, no escritor (e não no médico que Schnitzler também era), o seu duplo (Doppelgänger). Em tom confessional, Freud afirma que se sentira atormentado ao se perguntar por que não teria feito esforços para conhecêlo. Ao considerar o escritor Schnitzler como seu duplo, Freud revela algo de muito próprio à psicanálise: foi em relação a um autor literário, a um poeta/ criador (Dichter), e não a um médico-cientista, que Freud reconheceu um duplo. Vejamos os termos contidos no seguinte trecho desta carta:

Devo fazer-lhe uma confissão, que lhe pedirei ser bom o suficiente para guardá-la com o senhor e não a compartilhar com nenhum amigo. Importunei-me com a questão de como durante todos esses anos nunca procurei sua companhia e usufruí de uma conversa com o senhor (supondo que tal não lhe seria incômodo). A resposta é esta confissão extremamente íntima: penso que o evitei a partir de uma espécie de temor de encontrar meu "duplo" [Doppelgänger]. [. . . ] quando me vejo profundamente interessado por suas belas criaçôes, sempre pareço encontrar por trás do esplendor poético delas as mesmas pressuposiçōes, os interesses e conclusōes que me são familiares em meu trabalho. [.. . .] Tudo isso me toca com uma estranha sensação de familiaridade [unheimlichen Vertrautkeit] [. . . ]. Assim, ficou-me a impressão de que o senhor sabe por intuição - realmente, a partir de uma fina auto-observação - tudo o que tenho descoberto em outras pessoas por meio de laborioso trabalho [...] (Freud apud Jones, 1989, pp. 430-431, grifo nosso).

Transcorridos 15 anos, a harmonia inicial é agora transmudada numa estranha e perturbadora familiaridade (unheimlichen Vertrautkeit), e a euforia, por sua 
vez, transformada em temor ao duplo (Doppelgängerscheu) representado por Schnitzler. O que poderia significar essa inaudita confissão freudiana que situa o escritor-poeta (Dichter) como sendo o duplo do psicanalista?

O tema do "duplo" é tratado no artigo freudiano Das Unheimliche (Freud, 1919b/2014), substantivo de difícil tradução, pois abrange uma gama semântica que comporta a ideia daquilo que é terrível, assustador, e que desperta angústia e horror (Freud, 1919b, p. 33), uma estranheza inquietante (expressão adotada na versão francesa do artigo freudiano), e cuja tradução que utilizamos é "O estranho", adjetivo substantivado (como em alemão). Ao se debruçar sobre o que é característico no idioma alemão em relação ao significado do adjetivo unheimlich, perpassando um detido estudo etimológico nesse idioma, como também em outras línguas, Freud (1919b) conclui que o termo exprime uma peculiaridade: "Entre seus diferentes matizes de significado, a palavra heimlich (familiar) exibe um que é idêntico ao seu oposto, unheimlich" (Freud, 1919b, p. 41), assinalando a dimensão antitética desse vocábulo. Conclui, assim, que aquilo que é da ordem do heimlich poderia vir a ser unheimlich. É dessa maneira que podemos entender o fenômeno do estranho como algo que, pertencendo ao domínio do que é familiar, irrompe como elemento inassimilável a esse domínio, sendo, por conseguinte, radicalmente perturbador. Assim, é do próprio âmago do familiar, agradável e conhecido que brota o inquietante, oculto, estranho. Sob que condiçōes ocorreria esse reviramento?

De acordo com a argumentação freudiana, o fenômeno das Unheimliche ocorre quando algo que, em algum momento, foi familiar e conhecido provoca estranheza e horror; e que a partícula de negação un introduz a marca do recalcado (Freud, 1919b, p. 67). O recalque é o que faz com que isso que causa estranhamento não seja alheio, mas sim algo de interno (heimlich) à vida psíquica, tornando-se unheimlich.

No artigo intitulado $A$ negação, Freud (1925/2016) indica que a negativa (die Verneinung) é, paradoxalmente, uma forma de asserção referente ao conteúdo recalcado. Isto é, o recalcado emerge sob a forma da negação: "Por meio do símbolo da negação, o pensar se liberta das limitações do recalcamento e se enriquece de conteúdos dos quais não pode prescindir para seu desempenho" (Freud, 1925, p. 307,). Essa dimensão já havia sido apontada no livro A interpretação dos sonhos, quando Freud evidencia a relação excludente do sonho com o princípio da não contradição que preside o pensamento teórico-especulativo: "O 'não' parece inexistir no que concerne aos sonhos" (Freud, 1900, p. 212). Problemática que o próprio Freud retoma em 1910, ao tratar do sentido antitético de palavras primitivas, no artigo em que observa a coexistência de sentidos contraditórios e mutuamente excludentes em um mesmo vocábulo, em determinadas línguas 
primitivas, afirmando que o inconsciente não registra a negatividade. Logo, não é contraditório constatar que aquilo que é familiar (heimlich) emerja como estranho (unheimlich), isto é, de uma coexistência entre dimensões opostas, uma vez que o funcionamento inconsciente não é regido pelo princípio de não contradição.

Quanto ao tema do duplo (Doppelgänger), no campo psicanalítico, este foi inicialmente problematizado por Rank (2014) em sua obra homônima, na qual o fenômeno do duplo é investigado em sua relação com a imagem especular e também com as sombras, inspirando a discussão apresentada no artigo freudiano de 1919. No entanto Freud considera que nada do que foi tratado sobre o duplo poderia aproximar-se da magnitude da estranheza (Unheimlichkeit) que lhe é intrínseca. O duplo se converte "numa imagem aterrorizante, assim como os deuses, após a ruína de suas religiōes, se convertem em demônios." (Freud, 1919b, p. 56), citando o poeta alemão Heine (2009). Sua emergência diria respeito a algo que é projetado para fora do Eu sob a categoria do estranho (das Unheimliche).

Ao abordar o fenômeno do estranho, Freud relata uma experiência singular ocorrida durante uma viagem de trem. Estivera num vagão, sozinho, quando, em um movimento mais brusco da composição, a porta que conduzia ao toilette se abrira, e ele se deparara com um senhor idoso olhando-o fixamente. Freud, então, não tardou em levantar-se, a fim de adverti-lo. Eis que, com grande perplexidade, reconheceu que aquele que lhe interpelara com o olhar, era, de fato, apenas a sua imagem refletida no espelho. Não sentira medo de seu duplo; simplesmente não o reconhecera (Freud, 1919b).

Se a imagem refletida - mas não reconhecida - na superfície metálica assinala a emergência do duplo (Doppelgänger), não seria esta uma indicação precisa de que o fenômeno do duplo concerne àquilo que, no campo da imagem especular, é subtraído, logo, não é refletido, e, portanto, visto? É precisamente diante desse ponto de opacidade na imagem especular (conhecida e reconhecível, logo, heimlich), que irrompe o unheimlich, ponto cego diante do qual "Eu é um outro" (conforme a aguda percepção poética de Rimbaud). ${ }^{6}$ Ponto de ruptura narcísica, cuja consequência imediata parece implicar uma interpelação pelo outro que ele (não) é; donde o medo do duplo (Doppelgängerscheu). Retornaremos a esse ponto adiante.

Freud (1919b) assinala duas dimensões do duplo, que ocorrem a um só tempo: a primeira seria uma garantia contra a morte do Eu, no sentido de que a imagem reassegura a existência; ao passo que a segunda porta um prenúncio 
da morte ou ainda da castração. Apresenta seu argumento partindo da cultura do Egito antigo, afirmando que, nas artes, passou-se a representar a imagem do morto como uma garantia de sobrevivência; ou seja, a representação por uma imagem toma o lugar da ausência provocada pela morte. Essa concepção de que o duplo, aquele que se situa no avesso da vida - isto é, no âmbito da morte poderia servir de seu prolongamento mediante uma representação, surge, para Freud, no terreno do amor a si próprio, aquele de um narcisismo primário. Uma vez este tendo sido superado, o duplo passaria a ter um sinal invertido: não é mais uma garantia de sobrevivência, mas emerge como um estranho anunciador da morte (Freud, 1919b).

Recorrendo à cultura popular, Freud (1919b) relembra que o que se encontra associado à morte é usualmente considerado estranho (unheimlich), e, desse modo, eleva esse tipo de estranhamento ao seu patamar mais radical. A relação de completo desconhecimento que temos com a morte, aponta Freud, conservouse como nenhum outro tema no decorrer dos séculos. Nenhum saber forjado pelo homem jamais pode garantir o que quer que seja diante da morte. Se a garantia contra a morte é representada como uma das dimensões do duplo, então a imagem especular teria uma função apaziguadora.

No artigo O estádio do espelho como formador da função do eu, Lacan (1998) trata da precipitação de uma forma primordial constitutiva do Eu, no bebê, entre 6 e 18 meses de idade, a partir da assunção de sua imagem refletida no espelho, bem como pela outorga, por parte da palavra do Outro, que lhe dá forma. Destaca, dessa maneira, o que Freud já anunciara em Introdução ao narcisismo (Freud, 1914/1996), vale dizer, que o Eu não é uma instância psíquica inata, mas que requer uma nova ação psíquica, destacando que esta se dá por uma antecipação da unidade corporal - em relação a um corpo originariamente despedaçado, disjunto, em virtude da prematuração neurológica -, a partir da ratificação simbólica advinda do Outro: "Tu és [este]". De outra parte, assinala que, pelo próprio fato de o Eu se constituir alienado a uma imagem - que, de início, não é a sua -, a dimensão de desconhecimento lhe é intrínseca e constitutiva, conforme atestado pelo mito de Narciso, do qual Freud extrai o termo "narcisismo", de modo a assinalar o frágil estatuto do Eu, instância psíquica. Assim, é como outro que o Eu se apreende, por uma captura narcísica, alienado a uma imagem, mediada por uma intervenção simbólica que faz com que essa captura não seja mortífera.

Assim, é possível situar o fenômeno do duplo a uma espécie de fratura concernente à dimensão especular, vale dizer, narcísica, por intermédio de um corte na correspondência biunívoca entre o Eu e a imagem especular. Logo, não se trata de uma mera duplicação, mas, justamente, de uma espécie 
de escotoma no campo visual. Donde o traço de temor, de medo do duplo (Doppelgängerscheu) que acompanha a sua emergência. Assim, em vez de caracterizar uma cópia fiel e reasseguradora do Eu, o Doppelgänger indicaria um fenômeno de despersonalização subjetiva.

Se a assunção jubilatória da imagem especular caracteriza a operação psíquica denominada identificação, sendo esta "a transformação produzida no sujeito quando ele assume uma imagem” (Lacan, 1998, p. 97), não é possível considerar que o que se encontra em jogo entre o psicanalista e o escritor seja algo dessa ordem. Freud não se identifica a Schnitzler. Antes, o confesso temor ao duplo que Schnitzler encarna para Freud testemunha não um júbilo, mas, talvez, a presença da angústia, esta que se caracteriza por ser Objketloss - isto é, sem objeto, conforme a proposição freudiana (Freud, 1926/1976) -, portanto, sem imagem. Como no episódio do trem, a reticência de Freud em conhecer Schnitzler parece indicar que o escritor-poeta se situa no âmbito do não especularizável, hiância na qual a constituição da imagem especular revela o seu limite (Lacan, 19621963/2005), mas não do especular, conforme apontado em outro trabalho (Vorsatz, 2019).

Imagem sem objeto, como aquela contida na superfície opaca da porta do trem, em que Freud não se vê refletido, mas é interpelado pelo olhar de um estranho, resta a Freud nomear o inominável, Doppelgänger. Operação que caracteriza uma práxis, que consiste em tratar o real pelo simbólico (Lacan, 1964), a práxis psicanalítica por excelência.

\section{CONSIDERAÇÕES FINAIS}

Ao interrogar qual seria o estatuto do duplo no que concerne a relação entre o escritor (Dichter) e o psicanalista, conforme a asserção de Freud em relação à Schnitzler, verificamos que não se trata de uma relação de semelhança ou ainda de simetria. Na conhecida carta de 1922, Freud revelou ter encontrado "sob a superfície poética os mesmos pressupostos, interesses e conclusōes" que ele próprio sustentava em seu trabalho clínico, o que o comovera com "inquietante familiaridade" (unheimlichen Vertrautheit). A estranheza de Freud, ao reconhecer em Schnitzler o seu duplo, remete-se àquilo que, justamente, não o reflete, isto é, não devolve a ele uma imagem na qual pudesse se reconhecer (a sua, própria) logo, portadora de um caráter apaziguador.

Trata-se, antes, da emergência de algo que, interpelando-o precisamente onde Freud não se vê refletido, vale dizer, interrogando-o naquilo que lhe é mais próprio e constitutivo enquanto psicanalista ("Sempre pareço encontrar por trás 
do esplendor poético delas [as suas belas criações] as mesmas pressuposições, os interesses e conclusões que me são familiares em meu trabalho" - Freud apud Ernest Freud, 1982) confina com o temor do duplo (Doppelgängerscheu).

Nesse sentido, o escritor como duplo do psicanalista jamais poderia ser o seu sósia, ${ }^{7}$ isto é, seu igual. O duplo (Doppelgänger) não é uma réplica. Antes, por não caracterizar um mero reflexo, é assombroso. Schnitzler, nomeado por Freud como sendo o seu duplo, não é, portanto, a imagem (ideal) na qual Freud se veria refletido, mas, sim, aquele que é radicalmente desconhecido em sua estranha familiaridade.

7 Conforme propõe a tradução da carta de Freud a Schniztler, datada de 14 de maio de 1922, encontrada na edição brasileira da seleção efetuada por Ernst Freud (1982, pp. 396-397) da correspondência do pai entre 1873 e 1939. 


\section{REFERÊNCIAS}

Birman, J. (2000). A psicanálise e a crítica da modernidade. In R. Herzog (Org.). A psicanálise e o pensamento moderno. (pp. 159-180). Rio de Janeiro: Contra Capa.

Bracco, M. O. K. (2011). Freud e o Prêmio Goethe. Jornal de Psicanálise, 44(81), 253-258.

Elias, N. (1994). Da sociogênese dos conceitos de "civilização" e "cultura". In N. Elias. O processo civilizador: uma história dos costumes. (Vol. 1, pp. 23-64). Rio de Janeiro: Jorge Zahar, 1994.

Freud, E. L. (1960). Briefe 1873-1939. (p. 279). Frankfurt: Ernst L. Freud.

Freud, E. L. (1982). Sigmund Freud: correspondência de amor e outras cartas (1873-1939). Rio de Janeiro: Nova Fronteira.

Freud, S. (1895/1996). Estudos sobre a histeria. In J. Salomão (Trad.), Edição standard brasileira das obras psicológicas completas de Sigmund Freud. (Vol. 2, pp. 13-318). Rio de Janeiro: Imago, 1996. (Texto original publicado em 1895).

Freud, S. (1900/1996). A interpretação dos Sonhos. In J. Salomão (Trad.), Edição standard brasileira das obras psicológicas completas de Sigmund Freud. (Vols. 4, 5, pp. 15-700). Rio de Janeiro: Imago, 1996. (Publicado originalmente em 1900).

Freud, S. (1907/1977). Delírios e sonhos na Gradiva de Jensen. In J. Salomão (Trad.), Edição standard brasileira das obras psicológicas completas de Sigmund Freud. (Vol. 9, pp. 17-95). Rio de Janeiro: Imago, 1977. (Publicado originalmente em 1907).

Freud, S. (1908a/1996) A moral sexual civilizada e o nervosismo moderno. In J. Salomão (Trad.), Edição standard brasileira das obras psicológicas completas de Sigmund Freud. (Vol. 9, pp. 169-190) Rio de Janeiro: Imago, 1996. (Publicado originalmente em 1908).

Freud, S. (1908b/2015). O poeta e o fantasiar. In E. Chaves (Trad.), Obras incompletas de Sigmund Freud: arte, literatura e os artistas. (pp. 53-64). Belo Horizonte: Autêntica, 2015. (Publicado originalmente em 1908). 
Freud, S. (1910/2016). O sentido antitético das palavras primitivas. In E. Chaves (Trad.), Obras incompletas de Sigmund Freud: neurose, psicose e perversão. (pp. 59-67). Belo Horizonte: Autêntica, 2016. (Publicado originalmente em 1910).

Freud, S. (1913a/1997). El interés para la ciencia del arte. El interés del psicoanálisis para las ciencias no psicológicas. In Sigmund Freud: obras completas (Vol. 13, pp. 189-190). Buenos Aires: Amorrortu, 1997. (Publicado originalmente em 1913).

Freud, S. (1913b/2013). Totem e tabu: algumas concordâncias entre a vida psiquica dos homens primitivos e a dos neuróticos. (P. C. Souza, Trad.). São Paulo: Penguin Classics, Companhia das Letras, 2013. (Publicado originalmente em 1913).

Freud, S. (1914/1996). Introdução ao narcisismo. In J. Salomão (Trad.), Edição standard brasileira das obras psicológicas completas de Sigmund Freud. (Vol. 14, pp. 75-110). Rio de Janeiro: Imago, 1996. (Publicado originalmente em 1914).

Freud, S. (1919a/1996). Linhas de progresso na terapia psicanalítica. In J. Salomão (Trad.), Ediçāo standard brasileira das obras psicológicas completas de Sigmund Freud. (Vol. 17, pp. 169-182). Rio de Janeiro: Imago, 1996. (Publicado originalmente em 1919).

Freud, S. (1919b/2014). O estranho. In S. Freud. Escritos sobre a literatura de Sigmund Freud. (S. Krieger, Trad., pp. 33-77). São Paulo: Hedra, 2014. (Publicado originalmente em 1919).

Freud, S. (1920/1996). Além do princípio de prazer. In J. Salomão (Trad.), Edição standard brasileira das obras psicológicas completas de Sigmund Freud. (Vol. 18, pp. 135-198). Rio de Janeiro: Imago, 1996. (Publicado originalmente em 1920).

Freud, S. (1925/2016). A negação. In E. Chaves (Trad.), Obras incompletas de Sigmund Freud: neurose, psicose e perversão. (pp. 305-310). Belo Horizonte: Autêntica, 2016. (Publicado originalmente em 1925).

Freud, S. (1926/1976). Inibições, sintomas e ansiedade. In J. Salomão (Trad.), Edição standard brasileira das obras psicológicas completas de Sigmund Freud. (Vol. 20, pp. 107-200). Rio de Janeiro: Imago, 1976. (Publicado originalmente em 1926).

Freud, S. (1930a/2011). Mal-estar na civilização. (P. C. Souza, Trad.). São Paulo: Penguin Classics, Companhia das Letras, 2011. (Publicado originalmente em 1930). 
Freud, S. (1930b/1996). O prêmio Goethe. In J. Salomão (Trad.), Edição standard brasileira das obras psicológicas completas de Sigmund Freud. (Vol. 21, pp. 298-247). Rio de Janeiro: Imago, 1996. (Publicado originalmente em 1930).

Freud, S. (1932/1996). Por que a guerra? In J. Salomão (Trad.), Edição standard brasileira das obras psicológicas completas de Sigmund Freud. (Vol. 22, pp. 191208). Rio de Janeiro: Imago, 1996. (Publicado originalmente em 1932).

Heine, H. (2009). Os deuses no exílio. M. Suzuki, M., \& M. Kawano (Orgs.). São Paulo: Iluminuras.

Jones, E. (1989). A vida e a obra de Sigmund Freud. (Vol. 3). Rio de Janeiro: Imago.

Kon, N. M. (2014). Posfácio. In S. Freud. Escritos sobre a literatura de Sigmund Freud. (pp. 105-124). São Paulo: Hedra.

Lacan, J. (1962-1963). O seminário: livro 10: a angústia. (pp. 113-127). Rio de Janeiro: Jorge Zahar, 2005. (Publicado originalmente em 1962-1963).

Lacan, J. (1964). O seminário: livro 11: os quatro conceitos fundamentais da psicanálise. (pp. 9-20). Rio de Janeiro: Jorge Zahar,1988. (Publicado originalmente em 1964).

Lacan, J. (1998). O estádio do espelho como formador da função do eu. In J. Lacan. Escritos. (pp. 96-103). Rio de Janeiro: Jorge Zahar.

Lo Bianco, A. C. (1997). A Bildung germânica e cultura em Freud. Cadernos de Subjetividade, 5 (1), 117-131.

Maas, W. P. (2000). O cânone mínimo: o Bildungsroman na história da literatura. São Paulo: Editora Unesp.

Munk, L. (2008). A Viena de Arthur Schnitzler: variaçôes sobre a lei e o desejo, a razão e a desrazão. Rio de Janeiro: E-Papers.

Rank, O. (2014). O duplo: um estudo psicanalítico. Porto Alegre, São Paulo: Gradiva, Dublinense.

Rimbaud, A. (2006). Carta a Georges Izambard. Alea: Estudos Neolatinos, 8(1), 154-163. 
Rosa, J. G. (2005). O espelho. In J. G. Rosa. Primeiras estórias. (pp. 113-120). Rio de Janeiro: Nova Fronteira.

Roudinesco, E. (2016). Sigmund Freud na sua época e em nosso tempo. Rio de Janeiro: Jorge Zahar.

Trachtenberg, R. (2002). As duas (auto?) análises do Dr. Sigmund Freud. Federación Psicoanalítica de América Latina, Montevidéu. Recuperado a partir de http://fepal.org/wp-content/uploads/0348.pdf

Vorsatz, I. (2019). Freud e a ciência da literatura: psicanálise, ciência e poesia. Tempo Psicanalítico, 51(1), 159-184. 